\title{
A comparative analysis of the effectiveness of aquifer thermal energy storage in Expeditionary Campaign Infrastructure
}

Mark Hill ${ }^{a^{*}}$, Zahir Dehouche ${ }^{\mathrm{b}}$

${ }^{a}$ Royal School of Military Engineering, Chatham, Kent ME4 4UG. United Kingdom

${ }^{\mathrm{b}}$ Brunel University, Uxbridge, Middlesex UB8 3PH, United Kingdom

${ }^{*}$ Corresponding author at: Royal School of Military Engineering, Brompton Barracks, Chatham, Kent ME4 4UG, United Kingdom. E-mail addresses: mark.hill@hts.army.mod.uk, mhill6325@gmail.com (M. Hill), zahir.dehouche@brunel.ac.uk (Z. Dehouche).

Highlights

- Expeditionary Campaign Infrastructure energy usage is predicted on an annual basis.

- Aquifer thermal energy storage is considered for the reduction of energy usage.

- The model predicts significant energy savings and a favourable financial payback.

- Asymmetric seasonal demands affect ground temperatures adversely if left unchecked.

\begin{abstract}
A comparative study was undertaken to predict the energy savings associated with the employment of aquifer thermal energy storage in combination with a commercial water to air heat pump when used in Expeditionary Campaign Infrastructure against the climatic demands of Helmand Province, Afghanistan. Energy usage was predicted using EnergyPlus and the thermal response of the aquifer modelled using Processing SHEMAT based on predicted energy usage. The resulting analysis suggests a $22 \%$ reduction in fuel usage against an existing air to air heat pump with a $\mathrm{CO} 2$ reduction of 39 tonnes per annum. Although thermal stability of the aquifer could not be ensured without mitigation measures being undertaken, financially the analysis predicts a $£ 335,000$ per annum fuel saving assuming that the fully burdened cost of fuel is $\$ 11.98$ per litre thus offering a payback period of less than 2 years operation.
\end{abstract}

\section{Keywords:}

Expeditionary Campaign Infrastructure

Aquifer thermal energy storage

EnergyPlus

Processing SHEMAT

Energy saving

$\mathrm{CO} 2$ reduction

\section{Abbreviations.}

$\mathrm{ECl}$ - Expeditionary Campaign Infrastructure

FBCF - Fully Burdened Cost of Fuel

MoD - Ministry of Defence

UTES - Underground Thermal Energy Storage

GSHP - Ground Source Heat Pump

TES - Thermal Energy Storage

ATES - Aquifer Thermal Energy Storage 


\section{Introduction.}

The UK MoD has highlighted the need to reduce fossil fuel dependency, not only to meet its legal commitments but also to reduce the casualties and costs associated with fuel supply to remote and often hostile areas [1]. One area of high energy usage and thus high fuel usage is in the provision of accommodation for deployed personnel; this accommodation, both technical and domestic, is termed Expeditionary Campaign Infrastructure (ECI). This paper suggests that Aquifer thermal Energy Storage (ATES) could be employed in ECI to enhance the sustainability of military deployments and directly address financial and environmental concerns, it provides a ground coupled analysis of ATES when employed to meet the heating and cooling demands of a typical 250 person tented camp.

$\mathrm{ECl}$ is basic in nature and consists mainly of tentage with some more permanent facilities and provides the infrastructure from which a modern military force operates, it is therefore key to the successful deployment of a military force. Typical ECl is shown in Figure 1.

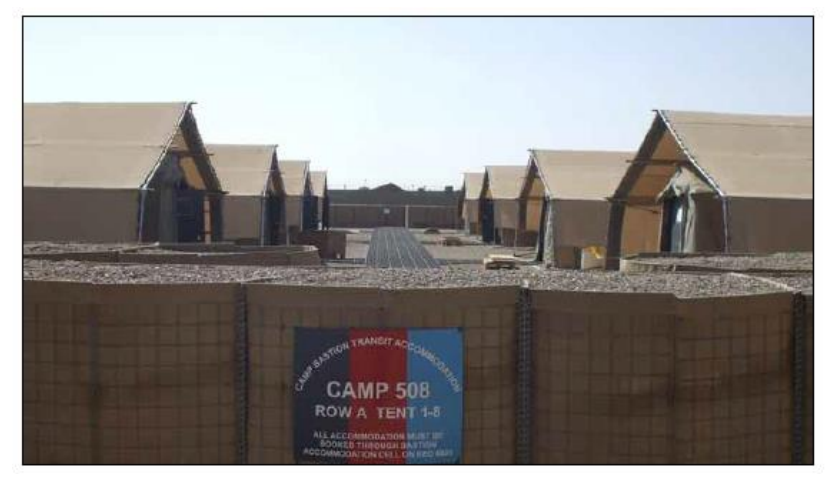

Figure 1. Expeditionary Campaign Infrastructure (ECI) consists largely of tented accommodation [2]

Occupant comfort in $\mathrm{ECl}$ is provided by air to air heat pumps similar to that shown in Figure 2, given the unique nature of military deployments $\mathrm{ECl}$ can be expected to be deployed in any climatic area thus energy usage could range from moderate, in temperate environments, to extreme when employed in areas where climatic conditions provide the greatest challenges, the current air to air heat pump used is specified to provide temperature control between $-10^{\circ} \mathrm{C}$ and $+60^{\circ} \mathrm{C}$ [2] and the electrical load is met by on site diesel powered generators.

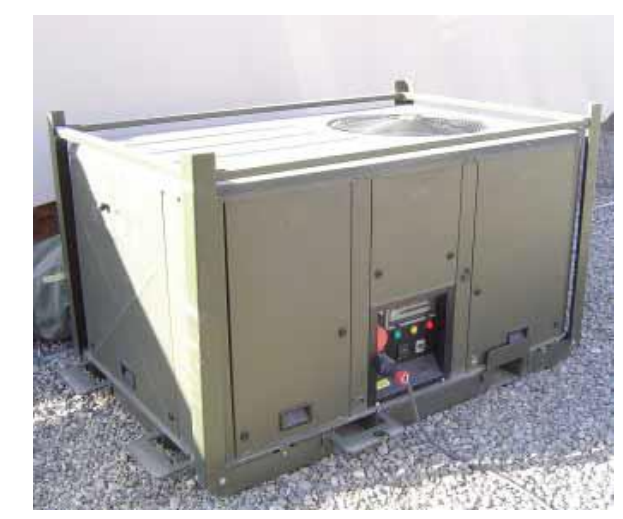

Figure 2. Typical ECl air to air heat pump [2].

With the current political climate it is likely that Expeditionary Campaign Infrastructure in some form will continue to be deployed in more extreme areas thus energy usage can be expected to remain high, the natural conclusion is therefore that an alternative to the air to air heat pump should be considered. In recent years there has been interest placed on the use of geothermal systems such as ground source heat pumps (GSHPs) or differing forms of underground thermal energy storage (UTES); Aquifer Thermal 
Energy Storage (ATES) is a subset of UTES. Whilst ground source heat pumps may be an established solution in permanent infrastructure, in the context of military operations they can be seen to be cumbersome and restrictive; specialist knowledge is required in order to install them, detailed analysis of ground conditions, limb spacing and grout types is required and the process is typically time consuming thereby being less acceptable as an expedient solution, in addition any military unit considering GSHPs would also have to invest in substantial training in order to install the ground coupled element of the system.

ATES has an advantage over the use of GSHPs; most military forces have a well drilling capability and already possess the skill, training and experience required to successfully develop wells that could then be exploited in an ATES scheme since the above ground plant is identical for either approach.

Energy savings for the most advanced ATES schemes can be dramatic; Andersson [3] showed a $90-95 \%$ reduction in heating and cooling when employed as a direct system and an $80-85 \%$ reduction when use in heat pump assisted mode. However there are very few long term studies to demonstrate continued efficiencies of this order since one of the main factors affecting any underground system is the need to consider a balanced thermal load within the ground throughout the life cycle of the installation; this consideration is in conflict with the thermal load of the asset that the system is attached to. Measures to compensate for an asymmetry in the overall heat balance between seasons are possible and include the use of water to water heat pumps, typically used to pre heat boiler water.

Very little is recorded in terms of military energy reduction through the use of TES and most initiatives concentrate on more effective power generation [4] although Jarrett [5] provided an analysis of the impacts of technological enhancements such as evaporative cooling, operating enhancements centred around the use of controls and material enhancements in the fabric of the accommodation structure itself, namely low ' $R$ ' value coatings. Jarrett recognised that the use of evaporative cooling would result in increased water usage (approximately $34 \%$ ) hence it would appear that ATES could be considered as a minimal loss system which is more appropriate given the existing requirement for borehole development.

This paper introduces a comparative study of energy reduction between the existing, energy intensive, air to air heat pump based system currently used in UK ECI and a simplified water to air heat pump system that incorporates ATES. Whilst most similar studies use EnergyPlus [6] to provide building heat loads before being transferred to TRNSYS or similar, see for instance O'Neil \& Rees [7]. This method maintains EnergyPlus throughout and couples the building load to the response of a commercial water to air heat pump. In doing so it recognises that quite often design temperatures required for abstraction and injection into the cold well and warm well, which are typically taken to be $6-12^{\circ} \mathrm{C}$ and $25^{\circ} \mathrm{C}$ respectively ([8], [9]) will not necessarily be within the capacity of the plant.

Once injection and abstraction temperatures have been determined the results were transferred to Processing SHEMAT [10], based on the USGS MODFLOW core [11], in order to understand the response of a typical aquifer under stress.

\section{Methodology}

The procedure used in the comparative study was to model the annual cooling and heating loads of a single tent using EnergyPlus in order to determine the electrical demand of the nearest air to air heat pump to that used in $\mathrm{ECl}$ and to compare this directly with the electrical demand for a water to water heat pump, assuming that it is coupled to an ATES scheme. The outlet temperatures for the water to air heat pump were controlled to simulate typical aquifer injection temperatures and passed to Processing SHEMAT on a 
monthly basis to determine how the aquifer responded, inlet temperatures to the EnergyPlus model were extracted from Processing SHEMAT, again on a monthly basis, based on the aquifer response until the simulation ended. This is shown in Figure 3.

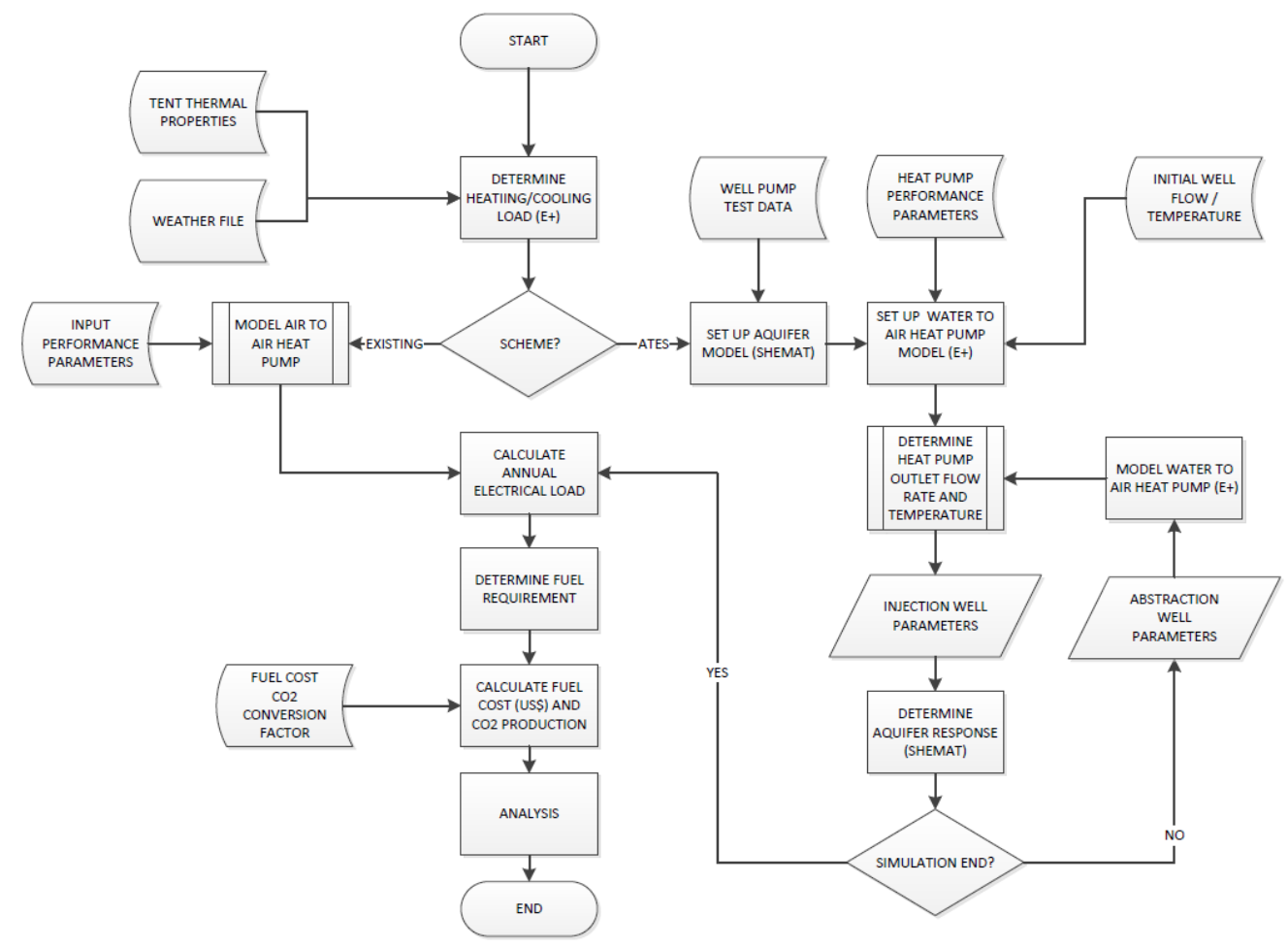

Figure 3. Procedure used to provide comparative study.

The analysis used Helmand province, Afghanistan, as the basis for comparison. A weather file generated for that area was used to inform the EnergyPlus model and the ATES was modelled as a simplified direct supply open loop system similar to that in Figure 4.

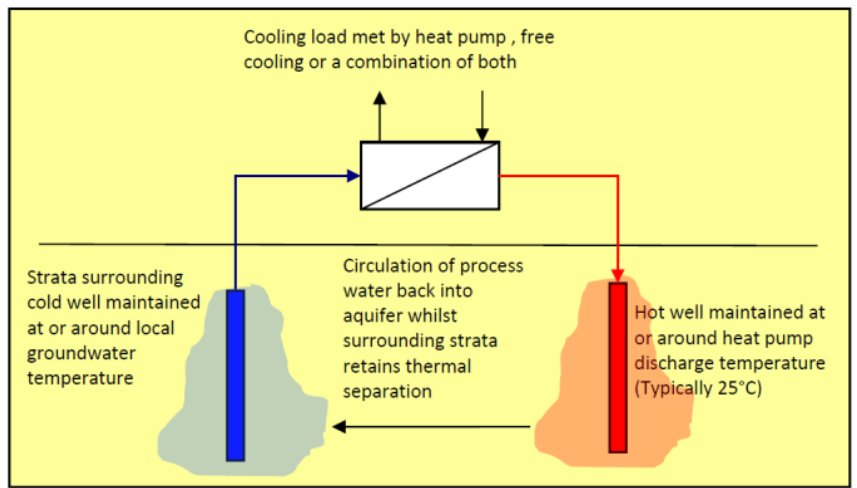

Figure 4. Schematic of a simplified ATES (summer cooling shown)

The EnergyPlus model for the tented structure was a 2 zone model which simulated the tent structure and sunshade as shown in Figure 5. 


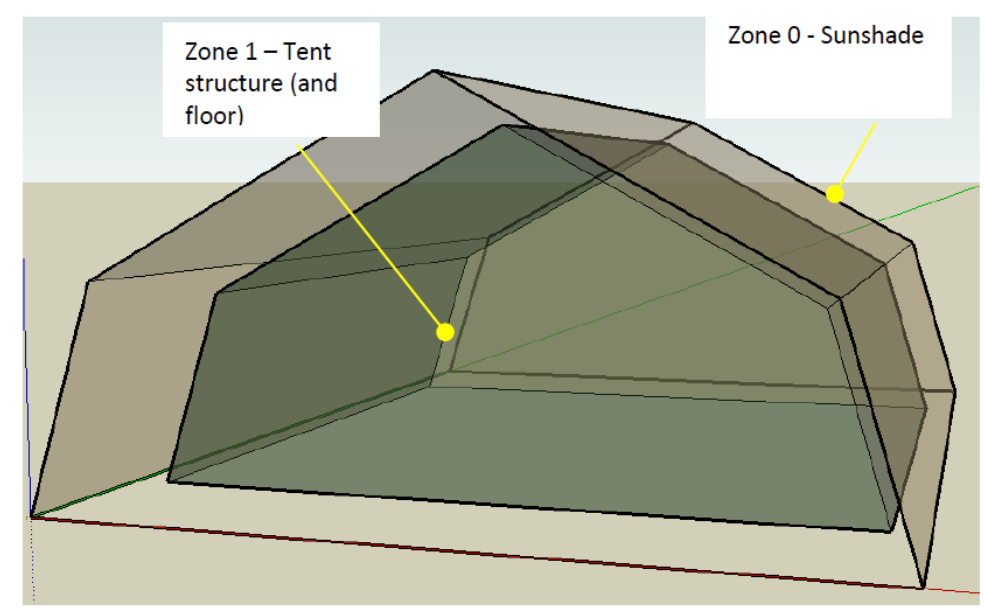

Figure 5. Graphical Depiction of the Tent EnergyPlus Model

The model parameters were based on common occupancy patterns $[7,12]$ and are shown in Table 1.

Table 1. Thermal model specifications used.

\begin{tabular}{lr}
\hline Parameter & Value \\
\hline Design summer temperature & $25^{\circ} \mathrm{C}$ \\
Design winter temperature & $20^{\circ} \mathrm{C}$ \\
Plant availability & $24 \mathrm{hrs} /$ day \\
Occupancy & 8 \\
Radiant heat gain & $131.9 \mathrm{~W} /$ Pers \\
Lighting occupancy & $16 \mathrm{hr} /$ day \\
Discontinuous plant operation? & Yes \\
\hline
\end{tabular}

The existing (air to air heat pump) system was modelled as per the performance specification of a Trane Voyager WDH 060 air/air heat pump, which represented the nearest unit to the modified version supplied to the MoD. The water to air heat pump (Trane model T1GX060) was selected from Trane as the closest match, in cooling capacity terms, and was modelled within EnergyPlus using Coil:heating:watertoairheatpump:equationfit and Coil:cooling:watertoairheatpump:equationfit modelling parameters. Equation fit coefficients were determined using the method detailed in the software literature [13] based on Tang [14].

Since an open loop model does not exist within EnergyPlus the plant was coupled to District Heating and District Cooling objects with setpoint managers to represent maximum and minimum well abstraction temperatures. Setpoint managers were adjusted at the end of one annual cycle and the simulation repeated at the higher setpoint temperature, the resulting average water to air heat pump inlet and outlet temperatures achieved from each run were then combined to determine the overall heat pump response. Once combined the resultant flow rates and temperatures were scaled to reflect the accommodation area of an $\mathrm{ECI}$, which consists of 32 individual accommodation tents. Other areas such as technical accommodation were not included in the resulting analysis. A schematic of the model is shown in Figure 6. 


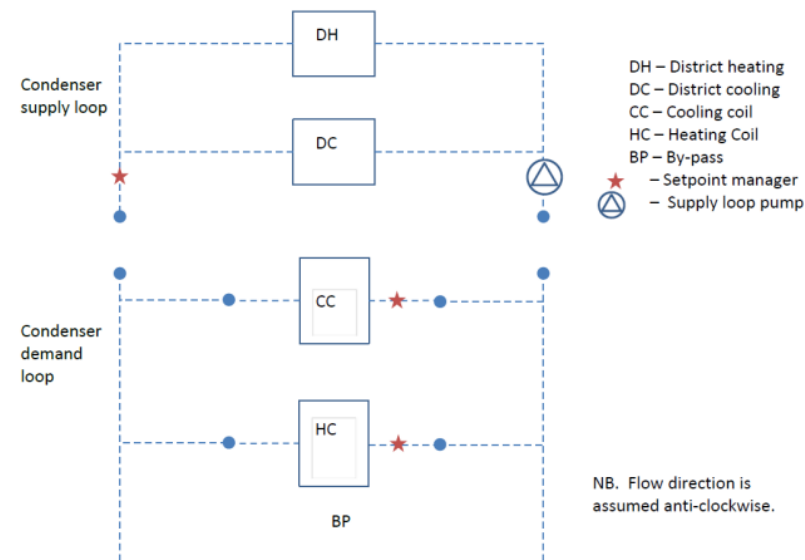

Figure 6. EnergyPlus model as constructed. Setpoint managers are included to simulate aquifer injection/abstraction conditions.

Subsurface data was based on well pump tests carried out in Afghanistan during 2010 to determine ground intrinsic permeability. After $50 \mathrm{~m}$ separation was discounted, $200 \mathrm{~m}$ well separation between the warm well and cold well was adopted as recommended by Banks [9] to prevent thermal interference between wells. The undisturbed groundwater temperature was calculated using the assumptions of Hillel [15] and thermal properties were those quoted for typical ground materials [16]. The specification used in the model is shown in Table 2.

Table 2. ATES specifications used in the model.

\begin{tabular}{lr}
\hline Parameter & Value \\
\hline Number of warm wells & 1 \\
Number of cold wells & 1 \\
Design warm well temperature & $25^{\circ} \mathrm{C}$ \\
Design cold well temperature & $9-12^{\circ} \mathrm{C}$ \\
Undisturbed groundwater temperature & $22^{\circ} \mathrm{C}$ \\
Soil thermal diffusivity & $0.00000112 \mathrm{~m}^{2} / \mathrm{s}$ \\
Basal heat generation of wells & $0 \mathrm{~W} / \mathrm{m}^{3}$ \\
\hline
\end{tabular}

\section{Results and discussion}

\subsection{Predicted flow rates.}

Predicted design flow rates for the water to air heat pump are shown in Table 3. Flow rates are provided as average monthly values and show that, as would be expected, the cooling season dominates. Total well abstraction/injection quantities were calculated as 131,494 $\mathrm{m}^{3}$ during the cooling season and 91,294 $\mathrm{m}^{3}$ during the heating season. Representing a $44 \%$ increase in water demand for cooling.

Table 3. Combined results of water to air heat pump conditions from EnergyPlus

\begin{tabular}{|l|l|l|l|l|}
\hline Month & Mode & $\begin{array}{l}\text { Flow rate } \\
\left(\mathrm{m}^{3} / \mathrm{s}\right)\end{array}$ & $\begin{array}{l}\text { Heat pump water } \\
\text { entry temperature } \\
\left({ }^{\circ} \mathrm{C}\right)\end{array}$ & $\begin{array}{l}\text { Heat pump } \\
\text { water exit } \\
\text { temperature } \\
\left({ }^{\circ} \mathrm{C}\right)\end{array}$ \\
\hline
\end{tabular}




\begin{tabular}{|l|l|l|l|l|}
\hline January & Heating & 0.00832 & 15.1 & 9.0 \\
\hline February & Heating & 0.00768 & 13.2 & 9.2 \\
\hline March & Heating & 0.00416 & 11.4 & 10.5 \\
\hline March & Cooling & 0.00256 & 10.5 & 11.5 \\
\hline April & Cooling & 0.00576 & 11.7 & 15.7 \\
\hline May & Cooling & 0.00896 & 12.0 & 19.8 \\
\hline June & Cooling & 0.00928 & 12.0 & 22.3 \\
\hline July & Cooling & 0.00800 & 12.0 & 19.7 \\
\hline August & Cooling & 0.00928 & 12.0 & 20.5 \\
\hline September & Cooling & 0.00576 & 11.8 & 16.2 \\
\hline October & Cooling & 0.00288 & 10.6 & 12.0 \\
\hline October & Heating & 0.00384 & 11.3 & 10.6 \\
\hline November & Heating & 0.00672 & 12.5 & 9.6 \\
\hline December & Heating & 0.00832 & 14.0 & 9.0 \\
\hline
\end{tabular}

This asymmetry is continued when considering the abstraction and injection heat rates. For the cooling season the total load is $1.51 \mathrm{MW}$, the heating season represents only $606 \mathrm{~kW}$ thus there is an additional 885 $\mathrm{kW}$ of heat rejected into the ground throughout the summer months.

\subsection{Aquifer response}

Using the flow rates and water to air heat pump rejection temperatures predicted in Table 3 the aquifer response was modelled using Processing SHEMAT [10] . Data for the aquifer was obtained from drilling logs collated during drilling operations in Helmand Province during 2010 and aquifer properties predicted using the Cooper-Jacob method [17]. Four drilling sites provided data for the analysis however no observation wells were used thus there is uncertainty in the results obtained due to the use of single well pump tests which provide a poorer estimate of mass permeability. For Processing SHEMAT analysis the intrinsic permeability of the aquifer, $k$, was taken as the average of the four well pump tests. Figure 7 shows the results of the pump tests for each individual well.

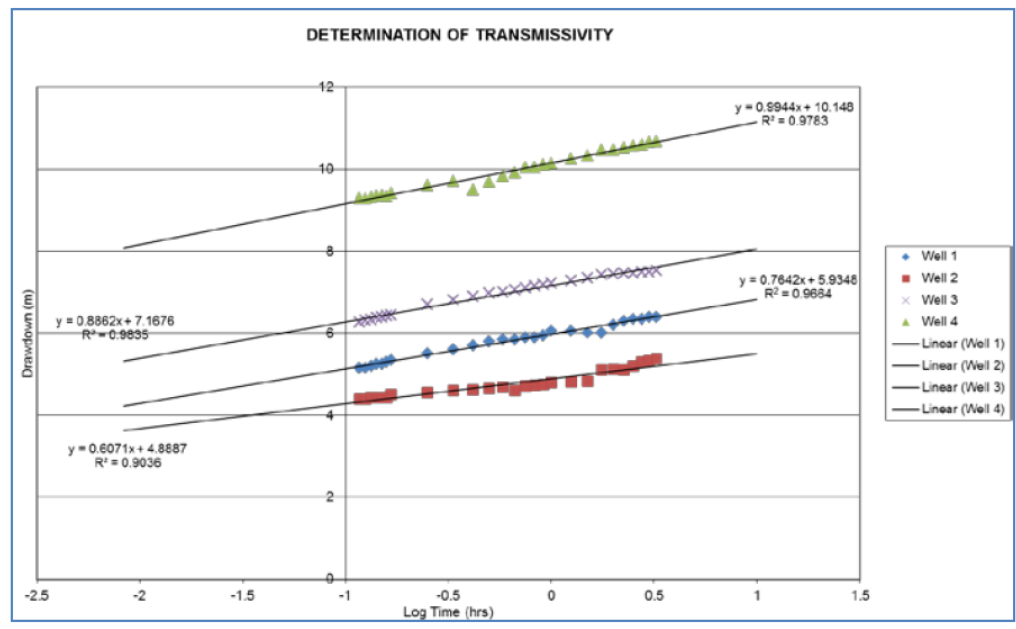

Figure 7. Well pump test results to determine transmissivity

Regression coefficients ranged from 0.9036 to 0.9783 thus appear reliable although in some cases it was unclear whether pumping reached steady state in order to confirm the validity of the Cooper-Jacob method. No details of the well casing were recorded and it was assumed that the well casing extended through the main aquifer to a depth of $20 \mathrm{~m}$, the standing water level of the wells was observed at $54 \mathrm{~m}$. From the well data, based on a $20 \mathrm{~m}$ well screen the intrinsic permeability was calculated for each well as shown in Table 4. 
Table 4. Calculated transmissivity and intrinsic permeability of wells from pump test data

\begin{tabular}{|l|l|l|}
\hline Well Number & Transmissivity $\left(\mathrm{m}^{2} /\right.$ day $)$ & Intrinsic permeability, $k,\left(\mathrm{~m}^{2}\right)$ \\
\hline 1 & 97.8 & $5.8 \times 10^{-15}$ \\
\hline 2 & 135.7 & $8.0 \times 10^{-15}$ \\
\hline 3 & 92.9 & $5.5 \times 10^{-15}$ \\
\hline 4 & 82.8 & $4.9 \times 10^{-15}$ \\
\hline
\end{tabular}

The results from Processing SHEMAT highlight the asymmetry in heating and cooling loads and predict that the cold well would be depleted within 8 months with a simulation start of October if a $200 \mathrm{~m}$ well separation is maintained and that the "cold" well would be depleted during each seasonal cycle before the heating season had ended due to the asymmetry of the heating and cooling loads, ultimately resulting in a temperature inversion of wells. These points are shown in Figure 8.

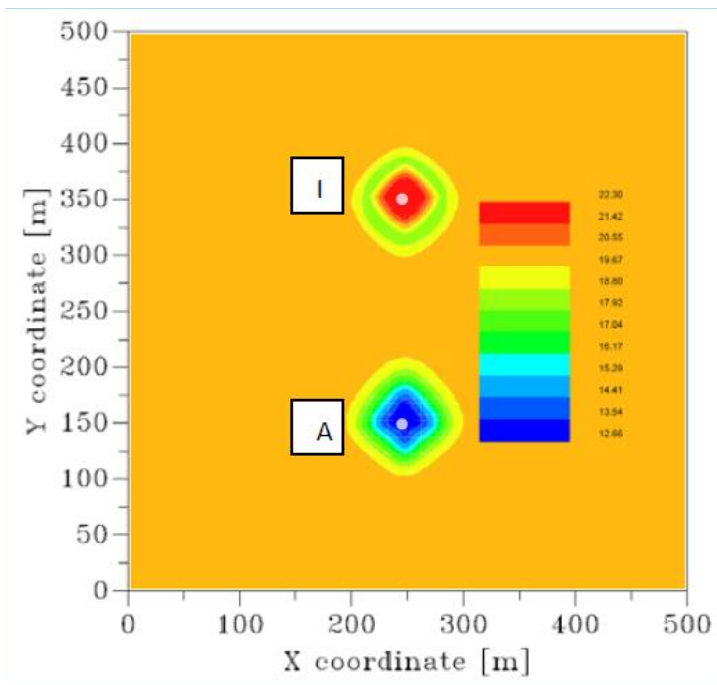

(a)

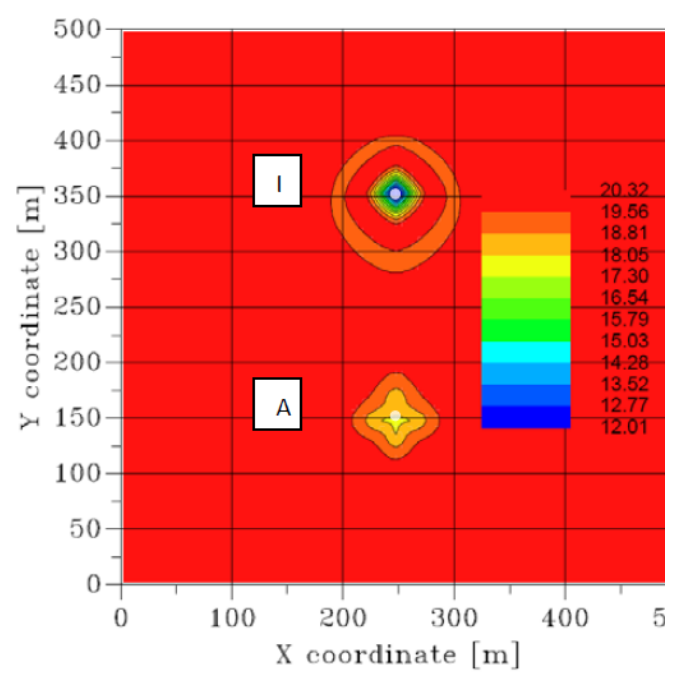

(b)

Figure 8. SHEMAT outputs showing borehole thermal depletion (a) and temperature inversion (b). Both occur in year one as a result of the asymmetric heating and cooling demands - 'I' denotes an injection well, 'A' an abstraction well

Assuming continuous use it was also predicted that thermal coupling of the injection and abstraction wells would occur without intervention after 7 years as shown in Figure 9. 


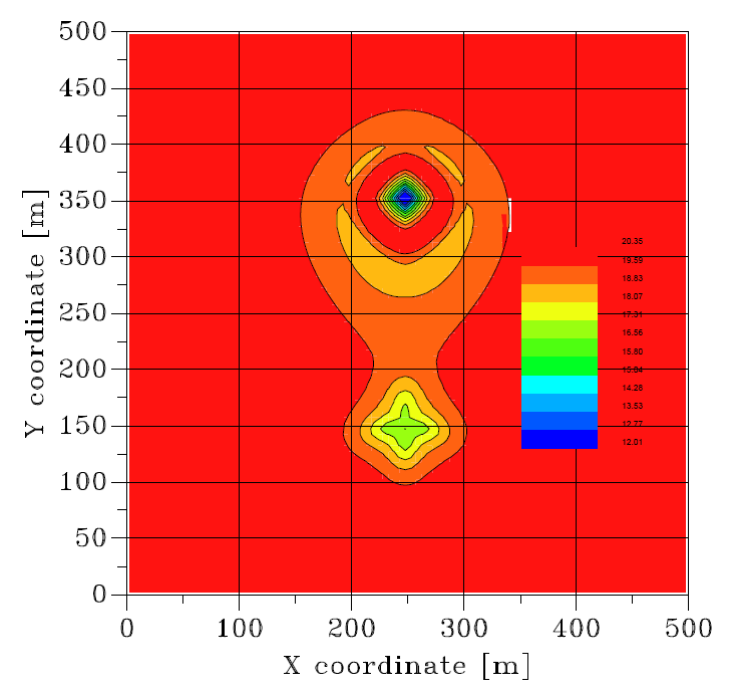

Figure 9. SHEMAT output showing 7 years simulated operation and thermal coupling of injection and abstraction wells

Although unimplemented in the simulation there are mitigation measures that could be undertaken. The two methods identified as being appropriate are the implementation of a hybrid system utilising cooling ponds to balance the heat pump heat rejection during the cooling season or, more beneficially in the context of military usage and fuel reduction, an extension of the system through the heating season to include water/water heat pumps for the preheating of domestic water sources for ablutions, cooking or laundry facilities. Neither approach is contentious and the appropriate plant and knowledge is already widely used outside of military applications.

\subsection{Energy reduction associated with ATES}

For the air/air heat pump (existing) the total yearly load, per tent, was forecast at 74. 2 GJ (20588.9 kWh), this reduces to $51.73 \mathrm{GJ}(16025.1 \mathrm{kWh})$ with the employment of a water/air heat pump. A breakdown of the energy requirements is shown in Table 5 .

Table 5. Energy consumption for air/air and water/air heat pumps.

\begin{tabular}{|l|l|l|l|l|}
\hline Energy usage & Case & $\begin{array}{l}\text { Energy } \\
\text { consumption } \\
\text { per year per } \\
\text { tent (GJ) }\end{array}$ & $\begin{array}{l}\text { Electrical load per } \\
\text { year per tent }(\mathrm{kWh})\end{array}$ & $\begin{array}{l}\text { Electrical load } \\
\text { per year per site } \\
\text { (32 tents) (kWh) }\end{array}$ \\
\hline \multirow{2}{*}{ Cooling } & Air/air heat pump & 34.9 & 9680.6 & 309777.8 \\
\cline { 2 - 5 } & Water/air heat pump & 18.2 & 5066.7 & 162133.3 \\
\hline \multirow{2}{*}{ Heating } & Air/air heat pump & 28.4 & 7888.9 & 252444.4 \\
\cline { 2 - 5 } & Water/air heat pump & 12.7 & 3522.2 & 112711.1 \\
\hline Fans & Air/air heat pump & 10.9 & 3019.4 & 96622.22 \\
\cline { 2 - 5 } & Water/air heat pump & 5.9 & 1655.6 & 52977.78 \\
\hline Pumps & Water/air heat pump & 20.8 & 5780.6 & 184977.8 \\
\hline
\end{tabular}

The decreased energy consumption associated with heating, cooling and fans is a direct consequence of the employment of water as a heat transfer medium (as opposed to air) which eliminates the seasonal variations associated with air/air heat pumps. It should be noted that ATES has an energy penalty associated with the need to account for the borehole pumps used to abstract and inject well water. This demonstrates a system sensitivity that is dependent on the depth at which water can be exploited and this energy increase can be expected to have a greater influence on the energy balance as the climate in which $\mathrm{ECl}$ is deployed 
becomes less severe than that modelled as part of this study. It is anticipated that there will always be an energy reduction regardless of climate but that groundwater levels must be considered before ATES is employed.

Table 5 shows that there is a considerable reduction in all energy areas not associated with the boreholes. Heating and cooling loads are reduced by approximately 16 GJ per year per year per accommodation tent, the largest comparative reduction being associated with heating (55\%) followed by cooling (48\%).

\subsection{Financial analysis}

In recent years the concept of the fully burdened cost of fuel (FBCF) has been introduced in order to quantify the probable cost of fuel necessary to undertake operations and various estimates have been made as to the value of the FBCF. Estimates range from $\$ 1.8 /$ itre to $\$ 11.8 /$ litre [18] and there is a sensitivity associated with that cost which is location specific, for the purposes of this study a FBCF of $\$ 11.8$ per litre was used based on planning updates reported by Schilke [19].

Based on a fully burdened cost of fuel of US\$ 11.98 per litre and specific fuel consumption of $0.2917 \mathrm{l} / \mathrm{kWh}$, calculated based on fuel consumption figures associated with the generator supplied for $\mathrm{ECl}$, with an annual discount rate of $3.5 \%$ [20] the employment of ATES was forecast to achieve payback within 2 years and realise savings of $£ 2.76 \mathrm{~m}$ over a 10 year period for a single 250 person camp. Details of the costs associated with borehole production and plant were not available so a notional cost of $£ 10,000$ per borehole with $£ 10,000$ per heat pump installation assumed as an initial outlay; maintenance and replacement of plant was not forecast.

The expected financial savings associated with heating, cooling and ancillaries on an annual basis are shown in Table 6.

Table 6. Breakdown of annual costs associated with ATES.

\begin{tabular}{|l|c|c|c|}
\hline Energy usage & $\begin{array}{l}\text { Electrical load saving (kWh) - } \\
\text { Water/air heat pump vs Air/Air } \\
\text { heat pump }\end{array}$ & Fuel saving (I) & $\begin{array}{l}\text { Financial saving } \\
\text { (\$m) }\end{array}$ \\
\hline Cooling & 147644.4 & 43067.9 & 0.516 \\
\hline Heating & 139733.4 & 40760.2 & 0.488 \\
\hline Fans \& pumps & -141333.3 & -41226.9 & -0.494 \\
\hline
\end{tabular}

The predicted financial saving is $\$ 0.51 \mathrm{~m}(£ 0.335 \mathrm{~m})$ per annum. This is limited, as previously mentioned, only by the depth at which water must be abstracted thus groundwater conditions must be assessed prior to commitment of any ATES undertaking to ensure that the system is financially viable before implementation.

\section{5 $\mathrm{CO}_{2}$ reduction.}

The reduction in fuel correlates directly to a reduction in $\mathrm{CO}_{2}$ emissions although no account was made for the decreased fuel requirements of delivery to site. Based on a $\mathrm{CO}_{2}$ factor of $0.2674 \mathrm{~kg} \mathrm{CO}_{2} / \mathrm{kWh}$ [21] the $\mathrm{CO}_{2}$ savings associated with the employment of ATES are shown in Table 7.

Table 7. Annual $\mathrm{CO}_{2}$ emission reductions associated with ATES

\begin{tabular}{|l|c|c|}
\hline Energy usage & $\begin{array}{l}\text { Electrical load saving (kWh) - } \\
\text { Water/air heat pump vs Air/Air } \\
\text { heat pump }\end{array}$ & $\begin{array}{l}\mathrm{CO}_{2} \text { emissions } \\
\text { reduction (Te/yr) }\end{array}$ \\
\hline Cooling & 147644.4 & 39.5 \\
\hline Heating & 139733.4 & 37.4 \\
\hline
\end{tabular}




\begin{tabular}{|l|l|l|}
\hline Fans \& pumps & -141333.3 & -37.8 \\
\hline
\end{tabular}

The net reduction in $\mathrm{CO}_{2}$ emissions is $39.1 \mathrm{Te} / \mathrm{yr}$ for a 250 person $\mathrm{ECl}$ camp, equating to approximately $156.2 \mathrm{~kg} \mathrm{CO} /$ person/year.

\section{Conclusions}

There is a significant financial and environmental saving associated with ATES that could be exploited in ECI. Based on a FBCF of US\$ 11.98 /I the employment of ATES for a single 250 person ECI Camp could achieve payback in less than 2 years and see a nett reduction in $\mathrm{CO}_{2}$ of $39.1 \mathrm{Te} / \mathrm{yr}$. Financially this could realise a saving of $\$ 2000 / \mathrm{yr} /$ person and $0.16 \mathrm{~kg} \mathrm{CO}_{2} / \mathrm{yr} /$ person - if scaled to a deployment size of 10,000 this suggests a potential to reduce $\mathrm{CO}_{2}$ emissions by $1600 \mathrm{Te} / \mathrm{yr} \mathrm{CO}_{2}$ and save $\$ 20 \mathrm{~m} / \mathrm{yr}$. Financial savings would be more modest if the FBCF is lower than that used but the potential for reducing the environmental impact in line with the stated aims of the MoD would remain.

The employment of a ground coupled model demonstrates that in an extreme climate where the cooling load dominates, thermal stability of the aquifer cannot be guaranteed and there would be a degradation of overall performance. In order to maintain the benefits of ATES mitigation measures would be required such as the use of a hybrid system utilising cooling ponds or, more favourably, the use of excess system heat in the preheating of domestic hot water. Less favourably and more difficult to achieve would be the employment of hydraulically separated aquifers.

\section{References}

[1] Ministry of Defence, "Sustainable Development Strategy - A Sub Strategy of the Strategy for Defence 2011 2030," [Online]. Available: zoads/system/uploads/attachment_data/file/32729/20110527SDStrategyPUBLISHED.pdf. [Accessed 19 July 2016].

[2] Ministry of Defence, "Operational Infrastructure (JTTP 4-05)," 5 February 2013. [Online]. Available: https://www.gov.uk/government/uploads/system/uploads/attachment_data/file/73187/jttp4_05_Op_Infra_Ed2.pdf. [Accessed 19 July 2016].

[3] O. Andersson, "Aquifer Thermal Energy Storage," in Thermal Energy Storage for Sustainable Energy Consumption (NATO Science Series II - VOI 234), vol. 234, H. O. Paksoy, Ed., Dordrecht, Springer, 2007, pp. 155-176.

[4] NATO, "Smart Energy' camp opens eyes to promising energy-saving solutions," 19 January 2015. [Online]. Available: http://www.nato.int/cps/en/natolive/news_101896.htm?selectedLocale=en. [Accessed 12 June 2015].

[5] J. E. Jarrett, "Expeditionary Campaign Infrastructure Modelling," Farnham, 2010.

[6] US Department of Energy, "EnergyPlus Energy Simulation Software," National Renewable Energy Laboratory (NREL), 31 March 2016. [Online]. Available: https://energyplus.net/. [Accessed 19 July 2016].

[7] Z. D. S. J. D. O'Neill and S. J. Rees, "Performance Aanalysis of Standing Column Well Ground Heat Exchanger Systems," ASHRAE transactions, vol. 112, no. 2, pp. 633-643, 2006.

[8] D. W. Bridger and D. M. Allen, "Designing Aquifer Thermal Energy Storage Systems," Building for the Future - $A$ Suuplement to ASHRAE Journal, vol. 47, no. 9, pp. S32-S37, 2005.

[9] D. Banks, An Introduction to Thermogeology. Ground Source Heating and Cooling., 2 ed., lowa: Wiley-Blackwell, 2012.

[10] J. Bartels, L. Z. Cheng, W.-H. C. C. Chiang, S. J. Hurter, M. Kuhn, V. Meyn, H. Pape, D. F. Pribnow, G. Ranalli, W. Schneider and H. Stofen, Numerical Simulation of Reactive Flow in Hot Aquifers - SHEMAT and Processing SHEMAT, C. Clauser, Ed., Berlin: Springer, 2003.

[11] US Geological Survey, "MODFLOW and Related Programs," 2005. [Online]. Available: 
http://water.usgs.gov/ogw/modflow/. [Accessed 10 May 2015].

[12] C. Yavuzturk, "Modeling of vertical ground loop heat exchangers for ground source heat pump system.PhD dissertation," Oklahoma State University, Stillwater, 1999.

[13] US Department of Energy, “EnergyPlus Documentation: Input Output Reference," 2012. [Online]. Available: http://apps1.eere.energy.gov/buildings/energyplus/energyplus_documentation.cfm. [Accessed 10 March 204].

[14] C. C. Tang, "Modelling Packaged Heat Pumps in a Quasi Steady State Energy Simulation Program," Department of Mechanical and Aerospace Engineering, Oklahoma State University, 2003.

[15] D. Hillel, Introduction to Soil Physics, San Diego: Academic Press, 1982.

[16] J. Busby, M. Lewis, H. Reeves and R. Lawley, "Initial geological considerations before installing ground source heat pump systems," Quarterly Journal of Engineering Geology and Hydrogeology, vol. 42, pp. 295-306, 2009.

[17] H. H. Cooper and C. E. Jacob, "A generalized graphical method for evaluating formation constants and summarizing well field history," American Geophysical Union Transactions, vol. 27, pp. 526-534, 1946.

[18] Deloitte LLP, “Energy Security: America's Best Defense," 2009. [Online]. Available: http://www.deloitte.com/assets/Dcom-

UnitedStates/Local\%20Assets/Documents/AD/us_ad_EnergySecurity052010.pdf. [Accessed 1 July 2014].

[19] R. Schilke, "USMC Expeditionary Energy Update. 2012 Joint Engineer Training Conference \& Expo," 2012. [Online]. Available: Available at: http://www.same.org/images/stories/T1_Session_3.pdf. [Accessed 1 June 2014].

[20] HM Treasury, The Green Book - Appraisal and Evaluation in Central Government, London: HMSO, 2011.

[21] Carbon Trust, "Conversion Factors - Energy and Carbon Conversions 2011 Update," 2011. [Online]. Available: http://www.carbontrust.com/media/18223/ctl153_conversion_factors.pdf. [Accessed 30 January 2016]. 